\title{
Ciências sociais e trabalho intelectual
}

\author{
ELIDE RUGAI BASTOS
}

RESUMO: O texto resenha Ciências sociais e trabalho intelectual, de Renato Ortiz (São Paulo, Olho d'água, 2002).

PALAVRAS-CHAVE: ciências sociais, pensamento sociológico.

O livro pode parecer, para o leitor desavisado, apenas um conjunto de estudos sobre autores - o que já seria bastante e, sem dúvida, de grande interesse e importância. Mas o texto é mais do que isso colocando e enfrentando problemas que centralizam a reflexão das Ciências Sociais.

Uma parte dessas questões encontra-se expressa e sistematizada no primeiro ensaio, outras são desenvolvidas nos estudos sobre autores, algumas ainda atravessam o trabalho como um todo. Sem pretender esgotar o assunto, que ganha excelente formulação no livro de Renato Ortiz, aponto algumas que me parecem fundamentais para uma revisita ao métier de sociólogo e que podem se configurar como críticas a alguns caminhos trilhados pelas políticas educacional e de pesquisa no país.

A indagação sobre o que é o trabalho intelectual aciona a reflexão. A operacionalização se dá a partir da pergunta - como se processa o trabalho intelectual? - para só depois discutir o que é esse trabalho e qual seu sentido. Assim, reconstruindo o processo, mostra que se trata de um fazer, procedimento que carrega consigo uma qualidade artesanal. Dessa característica resulta, de um lado, tratar-se de um artefato construído do IFCH - UNICAMP 
pedaço por pedaço, e de outro, ser uma construção referida à totalidade. Em se tratando das Ciências Sociais, cada pesquisa coloca questões diferentes ou, tratando-se da mesma problemática, de visões a partir de um outro ângulo. Por esse motivo, faz-se necessário refazer todos os passos da prática sociológica: investigação bibliográfica, pesquisa empírica, busca de fontes primárias, leituras diversas, anotações, seleção de material, elaboração de conceitos, escritura. Trata-se, pois, de um trabalho árduo e disso resulta a necessidade de um método para ancorar a reflexão. O autor aponta essa importância mostrando a centralidade da metodologia na análise dos diferentes autores enfocados.

A partir dessas considerações define o trabalho intelectual pelo que é e pelo que não é. Assim, é um projeto, uma ação deslocada para o futuro na qual o indivíduo se realiza por inteiro. É um trabalho em seu sentido profundo - não alienado, único, singular. Traz em si a idéia de incompletude, isto é, a próxima reflexão tem o poder/dever de acrescentar, criticar, renovar. Mais ainda, é resultado de um "demônio interior", que deve ser periodicamente alimentado. Não pode ser mensurado, ser visto a partir da quantificação das ações ou por sua mecânica aplicabilidade. Não deve ser confundido com a comercialização das idéias, com a burocratização do pensamento. Não pode ser prisioneiro da institucionalização das demandas do mercado, das fontes de financiamento ou dos prazos, pois, na maior parte das vezes, isto constrange a construção do objeto de pesquisa, que deve ser definido a partir de um amadurecimento das questões.

$\mathrm{O}$ tema desdobra-se na área das Ciências Sociais. Por que Ciências Sociais e não Sociologia, uma vez que Renato Ortiz analisa textos dos chamados pais da Sociologia ou clássicos contemporâneos da disciplina? Considerando que as Ciências Sociais vivem dos conceitos e que é necessário lapidá-los, mostra que os instrumentos da lapidação são vários e múltiplos. Disso decorre sua visão de articulação entre as diversas áreas. Trata-se da negação da fragmentação das Ciências Sociais, da afirmação de um diálogo que persiste apesar das estruturas universitárias, das políticas oficiais orientadoras da pesquisa. Em outro ângulo, da centralidade de uma multidisciplinaridade que não se reduz à engenharia social mas que se afirma como crítica.

É essa qualidade crítica que caracteriza as Ciências Sociais. É o que permite a ruptura com o senso comum - a depuração das noções do senso comum transformando-as em abstrações mais complexas, capazes de funcionar como categorias analíticas do pensamento. Esse traço resulta numa tensão. As Ciências Sociais operam a partir de um duplo movimento: tanto visam apreender a realidade como distanciam-se da realidade imediata, construindo uma outra espacialidade que permite o pensamento. É essa operação que permite ir além da aparência, revelar o oculto, ir além das consciências individuais. 
Esse campo tenso permeia toda a reflexão sociológica. Por exemplo, as teorias e os conceitos representam de um lado a independência da criação, da formulação do autor; de outro, devem encarnar-se em instituições - universidades, centros de pesquisa - que propiciam possibilidades de debates e conferem legitimidade às mesmas. Ou seja, as Ciências Sociais puderam progredir não apenas por causa das boas idéias, mas também pelo desenvolvimento dos centros de pesquisa, pela criação de bibliotecas, pela edição de revistas acadêmicas, pela realização de congressos e encontros científicos. Mas isso, que representou uma ampliação da atuação, pode levar a alimentar uma lógica mercantil, alheia ao trabalho acadêmico e submetida ao mundo midiático.

Um terceiro conjunto de questões diz respeito à produção do pensamento social, que no livro se explicita na análise dos diferentes autores - Durkheim, Escola de Frankfurt, Benjamin, Bourdieu - ou no balanço sobre as Ciências Sociais no Brasil. Em cada uma dessas análises Renato Ortiz mostra como os intelectuais dialogam com seu tempo e buscam, direta ou indiretamente, soluções para a questão social. Inserindo a reflexão no momento de sua produção, recupera não só o diálogo com os intérpretes anteriores, como aponta as diferentes fases do pensamento do autor. Tomo como exemplo o texto sobre As Formas Elementares da Vida Religiosa de Durkheim. A questão das continuidades e descontinuidades de sua argumentação contraposta aos livros escritos anteriormente não está referida apenas a um problema de lógica interna da proposta durkheimiana, mas direciona-se à forma pela qual esse autor opera uma reorganização dos conceitos. O procedimento também se aplica ao balanço que Renato Ortiz faz das contribuições dos diferentes cientistas sociais em relação àqueles que os antecederam.

Além disso indaga, ao analisar os autores que produziram no passado, sobre a contemporaneidade de sua obra. Essa contemporaneidade não reside apenas na permanência dos temas, mas principalmente na abertura dos mesmos para uma abordagem nova, que amplie o âmbito das Ciências Sociais. Volto ao exemplo da análise sobre As Formas Elementares da Vida Religiosa, onde Renato mostra que o texto de Durkheim pode ser colocado além de um estudo sobre a religião pois abre-se para a temática da ideologia. Em outros termos, como o tema permite descortinar um campo novo de reflexão que se constituirá em preocupações da sociologia contemporânea, da sociologia do conhecimento. Durkheim, ao colocar o problema do modo de apreensão do mundo - a representação permite o desdobramento da indagação em dois eixos - a forma e o conteúdo - isto é, o que é pensado e o modo de pensar. Simultaneamente a retomada de um problema colocado no passado pela filosofia e seu reflexo para o futuro da sociologia.

Assinalo, ainda, um texto que abre muitos temas à discussão: Notas sobre as Ciências Sociais no Brasil. Mobilizando os elementos 
que servem de base para as reflexões anteriores, o autor mostra como e porque a sociologia desenvolvida na Universidade de São Paulo entre os anos 1950 e 1960 explicita os rumos das Ciências Sociais no Brasil e a constituição do campo sociológico brasileiro. Não se trata apenas de pensar a contribuição inegável desses autores, mas de apontar para um momento em que essas ciências se institucionalizaram, em patamar diferente do de 1930. Analisar esse momento permite que explicite os resultado da repressão operada pela ditadura militar tanto no campo da estruturação da sociedade como na forma pela qual se organiza o pensamento. Este se traduz mais em relatórios de pesquisa e em papers do que em livros. Portanto, o período fornece uma visão fragmentada da situação social. A quase ausência de livros, dificultada pela restrição do debate, resulta no rompimento com uma tradição totalizadora que permitiria a síntese dos problemas abordados fragmentariamente. Em outras palavras, a intervenção do intelectual na sociedade far-se-á prioritariamente como engenharia social e pouquíssimo como crítica social.

O livro, que reúne trabalhos escritos em momentos diversos, tem uma clara linha que os unifica. Como se vê, trata-se de texto que coloca para a reflexão problemas centrais tanto para o trabalho intelectual como para o exercício das Ciências Sociais.

Recebido para publicação em setembro/2002

KEYWORDS:

Social Sciences, Sociological thinking.
BASTOS, Elide Rugai. Social Sciences and Intellectual Work. Tempo Social, Rev. Sociol. USP, S. Paulo, 14(2): 209-212, October 2002.

ABSTRACT: This text is a review of Ciências sociais e trabalho intelectual by Renato Ortiz (São Paulo, Olho d'água, 2002). 